Original Article

Artigo Original

Patrícia Danieli Campos ${ }^{1}$

Amanda Bozza ${ }^{1}$

Deborah Viviane Ferrari

Keywords

Hearing loss

Hearing aids

Hearing disorders

Audiology

Questionnaires

Descritores

Perda auditiva Auxiliares de audição Transtornos da audição Audiologia Questionários

Correspondence address:

Patrícia Danieli Campos

Alameda Octávio Pinheiro Brisolla, 9-75, Cidade Universitária, Bauru (SP), Brasil, CEP: 17012-901.

E-mail: patidanieli@usp.br

Received: 06/20/2013

Accepted: 01/14/2014

CoDAS 2014;26(1):10-16

\section{Hearing aid handling skills: relationship with satisfaction and benefit}

\author{
Habilidades de manuseio dos aparelhos de amplificação \\ sonora individuais: relação com satisfação e benefício
}

\begin{abstract}
Purpose: To evaluate hearing aid handling skills for new and experienced users and to assess if such skills influence user's benefit and satisfaction. Methods: Seventy four participants (mean age of 70.43), experienced $(\mathrm{n}=37)$ or new hearing aid users $(\mathrm{n}=37)$ performed the tasks of "Practical Hearing Aid Skills Test" (PHAST), which were scored on a five-point Likert scale - higher scores indicate better hearing aid handling skills. Experienced users answered the International Outcome Inventory for Hearing Aids (IOI-HA) and the hearing aid benefit for handicap reduction was calculated by the hearing handicap inventory (HHIA/HHIE). Results: Medians for PHAST total scores of 79 and $71 \%$ were obtained for experienced and new users, respectively there were no significant difference between groups. Lower PHAST scores were observed for the tasks of volume control manipulation and telephone usage. Moderate correlations were obtained between IOI benefit and quality of life items and the PHAST scores. There was no correlation between the results of PHAST and demographic data of the participants. Conclusion: There was no difference in handling skills between new and experienced hearing aid users. Handling skills affected hearing aid benefit.
\end{abstract}

\section{RESUMO}

Objetivos: Avaliar as habilidades de manuseio dos aparelhos de amplificação sonora individuais (AASIs) em usuários novos e experientes de tais dispositivos e verificar se estas habilidades influenciam no benefício e satisfação dos usuários. Métodos: Setenta e quatro indivíduos (média da idade de 70,43), usuários experientes $(\mathrm{n}=37)$ ou novos ( $\mathrm{n}=37$ ) de AASI, desempenharam as tarefas do instrumento "Habilidades Práticas de Manuseio do AASI" (PHAST), as quais foram pontuadas em uma escala Likert de cinco pontos — maiores pontuações indicam melhor habilidade de manuseio do AASI. Os usuários responderam ao inventário internacional de resultados com o AASI (IOI-HA) e também foi calculado o benefício do AASI quanto à restrição de participação (questionários de handicap auditivo - HHIA/HHIE) para estes indivíduos. Resultados: Medianas de pontuações totais do PHAST iguais a 79 e $71 \%$ foram obtidas para os usuários experientes e novos, respectivamente, não havendo diferença significativa entre os grupos. Maiores dificuldades foram observadas quanto à manipulação do controle de volume e uso do telefone. Foram obtidas correlações moderadas entre o item de benefício e qualidade de vida do IOI-HA e a pontuação do PHAST. Não houve correlação entre os resultados do PHAST e dados sociodemográficos dos participantes. Conclusão: Não houve diferença da habilidade de manipulação do AASI entre usuários novos e experientes. As habilidades de manipulação estavam relacionadas ao benefício obtido com o uso do AASI.

Study carried out at the Speech Language Pathology and Audiology Department, Dental School of Bauru, Universidade de São Paulo - USP - Bauru (SP), Brazil.

(1) Universidade de São Paulo - USP - Bauru (SP), Brazil.

Finnacial support: Institutional Scientific Initiation Program of USP - RUSP modality, for the support in the conduction of this study, process number 2012.1.04019.25.7.

Conflict of interests: nothing to declare. 


\section{INTRODUCTION}

The efficiency of individual hearing aid devices is confirmed for the treatment of most types of hearing impairment. Since 2000, the Unified Health System (SUS) provides different hearing aid devices, with various technologies, to the population, by means of authorized services. These actions were intensified in 2004, with the launch of the National Policy of Hearing Health Care ${ }^{(1)}$ and, more recently, with the Care Network for the Person with Impairment in SUS ${ }^{(2)}$.

From November 2004 to March 2013, all over Brazil 1177072 hearing aid devices were handed out by the hearing health care services of SUS ${ }^{(3)}$. Therefore, ensuring the effective use of these devices is important not only for the quality of life of the person with hearing impairment, but also for the correct use of public budget.

An international study ${ }^{(4)}$ observed that six months after the adaptation to a hearing aid device, about $40 \%$ of the individuals did not use it regularly, $30 \%$ could not insert it in the ear, and $80 \%$ could not handle it for telephone usage. Another study showed that among the $96 \%$ of experienced hearing aid users who reported the proper use of the devices, only $48 \%$ performed such tasks adequately ${ }^{(5)}$.

The proper handling of a hearing aid device is important to ensure the good adaptation and the functioning of the device, therefore avoiding the need of repairs and replacements, and especially making sure that the amplified signal is as clear as possible for the users ${ }^{(5)}$. This can affect the results obtained with the use of these devices.

As mentioned earlier, this study aimed at analyzing the handling skills with hearing aid devices among new and experienced users, and at observing if they related with the benefit and satisfaction of the user.

\section{METHODS}

A cross-sectional, correlational, and prospective study was carried out at the Speech Language Pathology and Audiology Clinic in the Dental School of Bauru, at the Universidade de São Paulo (FOB/USP), which was approved by the Research Ethics Committee of this institution (protocol no. 145/2009).

\section{Participants}

Seventy-four individuals voluntarily participated in this study after signing the informed consent, and they met the following inclusion criteria: to be regularly enrolled in the Speech Language Pathology and Audiology Clinic of FOB/USP, above 18 years old, user and main caretaker of the hearing aid device, not having visual changes that were not able to be corrected with lenses, not presenting with severe changes in manual skills and cognitive alterations according to the results of the Mini-Mental State examination (MMSE), translated to Brazilian Portuguese (BP) ${ }^{(6)}$.

Participants were divided into two groups according to time of hearing aid usage (Table 1):

- Experienced users: 37 individuals (22 men and 15 women), aged between 54 and 84 years old, being six adults and 31 elderly (above 60 years old), with sensorineural hearing impairment $(\mathrm{n}=30)$ and mixed impairment $(\mathrm{n}=7)$, users of hearing aid devices in unilateral $(\mathrm{n}=3)$ and bilateral adaptation $(\mathrm{n}=34)$ for a period of seven to 92 months;

Table 1. Characterization of participants $(n=74)$

\begin{tabular}{|c|c|c|c|}
\hline & $\begin{array}{l}\text { Experienced } \\
\qquad(\mathrm{n}=37) \\
\mathrm{n}(\%)\end{array}$ & $\begin{array}{c}\text { New } \\
(n=37) \\
n(\%)\end{array}$ & $\begin{array}{c}\begin{array}{c}\text { Total } \\
(\mathrm{n}=74) \\
\mathrm{n}(\%)\end{array} \\
\end{array}$ \\
\hline Age $($ mean $\pm S D)$ & $70.00 \pm 10.58$ & $70.90 \pm 13.03$ & $70.43 \pm 11.79$ \\
\hline Right ear & $51.99 \pm 18.81$ & $47.70 \pm 13.08$ & $49.85 \pm 16.23$ \\
\hline Months of hearing aid usage (mean $\pm S D$ ) & $32.0 \pm 24.0$ & $2.0 \pm 2.0$ & $17.0 \pm 23.0$ \\
\hline \multicolumn{4}{|l|}{ Type of hearing aid } \\
\hline Intracanal & $5(13.51)$ & 7 (18.92) & $12(16.22)$ \\
\hline Microcanal & $5(13.51)$ & $5(13.51)$ & $10(27.02)$ \\
\hline Open fit tube & $3(8.11)$ & $1(2.70)$ & $4(10.81)$ \\
\hline \multicolumn{4}{|l|}{ Socioeconomic classification } \\
\hline Inferior low & $6(16.22)$ & $2(5.40)$ & $8(10.81)$ \\
\hline Superior low & $22(59.46)$ & $28(75.67)$ & $50(67.57)$ \\
\hline \multicolumn{4}{|l|}{ Schooling } \\
\hline Illiterate & $3(8.11)$ & $4(10.81)$ & $7(9.46)$ \\
\hline Incomplete elementary & $19(51.35)$ & $17(45.94)$ & $36(48.64)$ \\
\hline Complete elementary & $8(21.62)$ & $6(16.21)$ & $14(14.91)$ \\
\hline High school & $2(5.40)$ & 7 (18.92) & $9(12.16)$ \\
\hline University & $5(13.51)$ & $3(8.11)$ & $8(10.81)$ \\
\hline
\end{tabular}

Caption: $\mathrm{SD}=$ standard deviation; ISO = hearing thresholds in the frequencies of $500,1 \mathrm{k}, 2 \mathrm{k}$, and $4 \mathrm{kHz}$ 
- New users: 37 individuals (20 men and 17 women), aged between 47 and 88 years old, being 11 adults and 26 elderly, with sensorineural hearing impairment $(n=34)$ and mixed impairment $(\mathrm{n}=3)$, users of a hearing aid device in unilateral $(n=2)$ and bilateral adaptation $(n=35)$ for a period of one to six months.

The data concerning socioeconomic status and schooling were extracted from the medical records of the participants. The time of hearing aid usage was considered from the date the device was provided until the date of applying the procedures of this research.

\section{Procedures}

The instrument Practical Hearing Aid Skills Test (PHAST) $)^{(5)}$ was used. The translation of this instrument to $\mathrm{BP}$ was conducted prior to this study ${ }^{(7)}$ according to the following steps ${ }^{(8)}$ :

- PHAST was translated to BP by three different translatorsinterpreters of English who had no previous knowledge of this instrument;

- Translations were given to three Speech Language pathologists, who were fluent in English and worked in the Audiology field, for an independent evaluation and choice of the most effective one for the Brazilian reality;

- The translation (Brazilian version), which was selected by at least two out of the three Speech Language pathologists, was sent to other three translators with proficiency degrees in English, who conducted the back-translation independently, from BP to English. This new version in English was analyzed again by the Speech Language pathologists, being then compared to the original version of PHAST, in order to conduct grammatical and idiomatic revision.

PHAST contains eight tasks related to hearing aid usage and handling:

1. Removing the hearing aid device: (a) skill to hold and (b) remove the devices from the ear;

2. Opening of the battery compartment: (a) locating and (b) opening the battery compartment;

3. Changing batteries: (a) removing the old battery and (b) inserting the new one;

4. Cleaning the hearing aid device: cleaning the (a) canal for sound exit, (b) microphone, and (c) ventilation opening;

5. Inserting the hearing aid device: (a) skill to hold and (b) to insert the devices in the ear;

6. Manipulation of volume control;

7. Telephone usage: (a) proper use of the software or phone bobbin and (b) placement of the telephone in relation to the ear;

8. Use of a directional microphone or software for noisy environments.

PHAST was applied in one of the return appointments of the patient to the Speech Language Pathology and Audiology Clinic. One evaluator, who had been previously trained for the application of this instrument, asked the participant to conduct each task and scored the level of skill according to the fivepoint Likert scale:

- Excellent (four points): the participant concludes the task without any mistakes;

- More than satisfactory (three points): the participant makes one mistake, however, still completes the task successfully;

- Satisfactory (two points): the participant makes more than one mistake, but concludes the task successfully;

- Less than satisfactory (one point): the participant tries to conduct the task, but cannot conclude it successfully, or requires other means to conclude it - for instance, removing the device from the ear in order to adjust volume control;

- Did not execute it (zero point): the participant cannot execute the task.

It is worth to notice that a revised version of PHAST was proposed, called PHAST- $\mathrm{R}^{(9)}$, addressed to clinical use with the use of a three-point Likert scale: cannot execute the task (zero point), performs the task with some difficulty (one point), and performs the task without difficulties (two points). However, for the purpose of this study, it was chosen to use the original instrument in order to obtain more details as to the skills in the execution of individual tasks.

The total score of PHAST, for each participant, was given by adding the points of each task. The maximum possible score ranged according to the applicability of questions (for instance, if one hearing aid device had automatic volume control, task 6 is not analyzed), therefore reaching up to 32 points.

In order to obtain the percentage of correct answers, the total score obtained for each participant was divided by the maximum possible score, and then multiplied by 100 . From this percentage, the performance of the user at manipulating his or her hearing aid device was classified as excellent (90-100\%), good $(80-89 \%)$, reasonable $(65-79 \%)$, or poor (lower than $65 \%)^{(5)}$.

The evaluation of results with the use of amplification was conducted only in a group of experienced users, since the scores of the self-evaluation scores can be increased during the first three months of using the device ${ }^{(10)}$. The benefit of the hearing aid device was observed in the restriction of participation, by means of hearing handicap questionnaires for adults - Hearing Handicap Inventory for Adults (HHIA) ${ }^{(11)}$ and elderly Hearing Handicap Inventory for Elderly (HHIE) $)^{(12)}$, translated to $\mathrm{BP}^{(13,14)}$. In order to assess the use and the satisfaction with the devices, participants also answered the International Outcome Inventory for Hearing Aids (IOI-HA) ${ }^{(15)}$.

The HHIA and HHIE questionnaires are composed of 25 questions divided into two subscales: social (12 questions that measure the effects of hearing loss in different social situations) and emotional (13 questions that estimate the attitudes and emotional responses of the individual with regard to his or her hearing impairment). For each question, there are three response alternatives: "yes" (equivalent to four points), "sometimes" (two points), and "no" (zero point). The score was analyzed manually, and the total was calculated (sum of points for the 25 questions), as well as the emotional and social subscales, 
separately. The total score can range from zero to 100 , and the higher the score, the higher the perception of disadvantages resulting from hearing loss ${ }^{(11,12)}$.

The IOI-HA is composed of seven questions, each of them with five response options, which are equivalent to values from one to five disposed gradually, from the left to the right, so that the first option indicates the poorest performance (one), and the last, the best performance (five). The score of the questionnaire was conducted manually. The results of IOI-HA can be analyzed from the score of each item, individually, or by the sum of them. The higher the score, the better the result with the use of the hearing aid device ${ }^{(15)}$.

As part of the routine in the Speech Language Pathology and Audiology Clinic, the HHIA/E questionnaires are applied before the process of selection and adaptation of the hearing aid device, and these dates were registered in the medical records of patients. Therefore, the benefit provided by the hearing aid usage was calculated by subtracting the score of the questionnaire which was obtained with and without the use of hearing aid devices.

All of the questionnaires were applied as interviews. The professional read the items and asked each participant to mark the alternative that was most similar to his or her judgment.

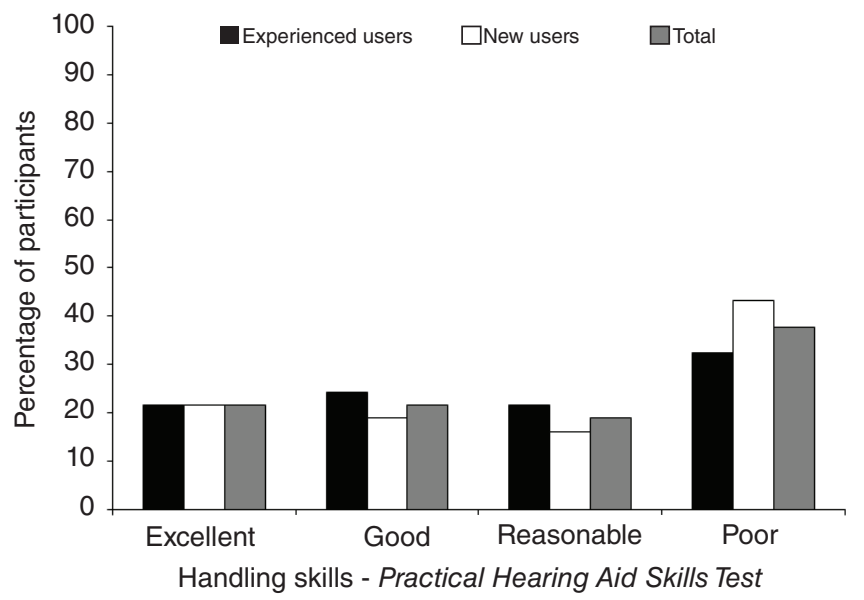

Figure 1. Classification of the handling skills of the hearing aid device $(n=74)$
Statistical analysis was conducted with the R software. Since the data did not present normal distribution, non-parametric tests were used. The Bonferroni correction was used to define the level of significance (p) when statistical tests were simultaneously conducted. The Wilcoxon test was used to compare age, schooling, hearing threshold in the best ear, and PHAST score between groups. In order to verify if there was a relationship between PHAST results and the ones of the HHIA/E and IOI-HA questionnaires, the Spearman correlation was applied.

\section{RESULTS}

The Wilcoxon test did not reveal significant differences between groups concerning age $(\mathrm{p}=0.54)$, schooling $(\mathrm{p}=0.82)$, socioeconomic status $(\mathrm{p}=0.67)$, hearing threshold in the best ear $(\mathrm{p}=0.47)$, and type of hearing aid device $(\mathrm{p}=0.99)$.

The percentage of the total score obtained in PHAST ranged from 32 to $100 \%$ (experienced users) and from 29 to $100 \%$ (new users). Figure 1 represents the percentage distribution of participants according to the classification obtained in PHAST.

Since only two experienced and four new users presented with a second acoustic software activated in their hearing aid devices, "task 8" from PHAST was not considered for analysis (Table 2).

The results of the self-assessment questionnaires and their relationship with the handling skills with hearing aid devices are shown in Tables 3 and 4, respectively.

\section{DISCUSSION}

At first, it is important to mention there was great diversity of handling skills with hearing aid devices, both among experienced (PHAST score ranging from 32 to $100 \%$ ) and for new users (ranging from 29 to 100\%). A study observed PHAST scores for new hearing aid users ranging from 60 to $100 \%{ }^{(16)}$. Other studies with experienced hearing aid users observed changes in the total PHAST score, between 48.0 and $100.0 \%^{(5)}$ and 61.2 and $100.0 \%$.

It was observed that $43 \%$ of new hearing aid users presented poor handling skills with the device (Figure 1).

Table 2. Comparison of results of the Practical Hearing Aid Skills Test between groups $(n=74)$

\begin{tabular}{|c|c|c|c|c|c|c|c|}
\hline \multirow[t]{2}{*}{ PHAST tasks } & \multicolumn{3}{|c|}{$\begin{array}{c}\text { Experienced users } \\
(\mathrm{n}=37)\end{array}$} & \multicolumn{3}{|c|}{$\begin{array}{l}\text { New users } \\
(n=37)\end{array}$} & \multirow{2}{*}{$\begin{array}{l}\text { Wilcoxon } \\
\text { p-value }\end{array}$} \\
\hline & Median & $\mathrm{P} 25 \%$ & $\mathrm{P} 75 \%$ & Median & P25\% & P75\% & \\
\hline Removing device & 4 & 4 & 4 & 4 & 3 & 4 & 0.38 \\
\hline Opening battery & 4 & 3 & 4 & 4 & 4 & 4 & 0.25 \\
\hline Changing battery & 4 & 3 & 4 & 4 & 3 & 4 & 0.75 \\
\hline Cleaning device & 3 & 2 & 4 & 3 & 1 & 4 & 0.20 \\
\hline Inserting device & 3 & 2 & 4 & 3 & 1 & 4 & 0.93 \\
\hline Manipulating volume & 3 & 1 & 4 & 2 & 1 & 4 & 0.46 \\
\hline Telephone usage & 2 & 1 & 4 & 2 & 1 & 2 & 0.27 \\
\hline Total & 22 & 17 & 26 & 20 & 16 & 25 & 0.52 \\
\hline$\%$ PHAST & 79 & 61 & 89 & 71 & 54 & 89 & 0.58 \\
\hline
\end{tabular}

Bonferroni correction: $\mathrm{p}<0.005$ statistically significant

Caption: PHAST = Practical Hearing Aid Skills Test; $\mathrm{P}=$ percentile 
Table 3. Benefit obtained in the questionnaires Hearing Handicap Inventory for Adults and Hearing Handicap Inventory for Elderly, and results from the International Outcome Inventory for Hearing Aids for experienced users $(n=37)$

\begin{tabular}{lccc}
\hline & \multicolumn{3}{c}{ Experienced users } \\
\cline { 2 - 4 } & Median & P25\% & P75\% \\
\hline Total HHIA/E & 34 & 14 & 48 \\
Social HHIA/E & 18 & 8 & 28 \\
Emotional HHIA/E & 14 & 6 & 22 \\
IOI 1 - Usage & 5 & 4 & 5 \\
IOI 2 - Benefit & 5 & 4 & 5 \\
IOI 3 - Limitation of residual activity & 4 & 4 & 5 \\
IOI 4 - Satisfaction & 5 & 4 & 5 \\
IOI 5 - Restricted participation & 5 & 4 & 5 \\
IOI 6 - Impact of device on other people & 5 & 4 & 5 \\
IOI 7 - Quality of life & 4 & 4 & 5 \\
\hline
\end{tabular}

Caption: HHIA = Hearing Handicap Inventory for Adults; HHIE = Hearing Handicap Inventory for Elderly; IOI = International Outcome Inventory

Table 4. Spearman correlation ( $r$ ) between the results of the Practical Hearing Aid Skills Test and the results of the questionnaires Hearing Handicap Inventory for Adults and Hearing Handicap Inventory for Elderly, and results of the International Outcome Inventory for Hearing Aids for experienced hearing aid users $(n=37)$

\begin{tabular}{|c|c|c|}
\hline & \multicolumn{2}{|c|}{ PHAST (\%) } \\
\hline & $\begin{array}{c}\text { Correlation } \\
\text { coefficient (rho) }\end{array}$ & $p$-value \\
\hline \multicolumn{3}{|l|}{$\mathrm{HHIA} / \mathrm{E}$} \\
\hline Total & 0.19 & 0.267 \\
\hline Social & 0.21 & 0.203 \\
\hline Emotional & 0.24 & 0.155 \\
\hline \multicolumn{3}{|l|}{$\mathrm{IOI}$} \\
\hline Usage & 0.24 & 0.016 \\
\hline Benefit & $0.45^{\star}$ & $0.005^{\star}$ \\
\hline Limitation of activity & 0.25 & 0.134 \\
\hline Satisfaction & 0.38 & 0.021 \\
\hline Restricted participation & 0.21 & 0.220 \\
\hline Impact on others & 0.15 & 0.357 \\
\hline Quality of life & $0.50^{*}$ & $0.005^{\star}$ \\
\hline
\end{tabular}

*Significant values $(p \leq 0.005)$

Caption: PHAST $=$ Practical Hearing Aid Skills Test; HHIA = Hearing Handicap Inventory for Adults; HHIE = Hearing Handicap Inventory for Elderly; IOI = International Outcome Inventory

This high incidence of individuals with unsatisfactory performance is in accordance with other studies that observed the handling of hearing aid devices is among the major difficulties found during the adaptation process ${ }^{(4,17)}$. About $47 \%$ of the experienced users showed good or excellent handling skills, which corroborates international literature ${ }^{(5)}$. However, it is important to mention that despite the time of hearing aid usage, $32.4 \%$ of these individuals cannot manipulate their device properly.

The median of the total PHAST score was higher among experienced (79\%) than new users (71\%), however, this difference was not significant. There was no significant difference between groups when the individual PHAST tasks were compared (Table 2).

Participants presented more difficulties in the manipulation of volume control (new users) and telephone usage (new and experienced users). Learning how to use the hearing aid device to hear the telephone is a difficult task for new users, considering they must place the telephone hook properly in relation to the microphone (however, without creating microphony) or to the telephone bobbin of the device. In the latter, individuals must also know how to activate the telephone bobbin to capture the electromagnetic signal coming from the telephone, and, if necessary, how to adjust the volume control of the hearing aid device in order to increase such capture.

Experienced users also had lower score in PHAST with regard to telephone usage and the noise software ${ }^{(5)}$. Other studies demonstrated that approximately $43 \%$ of the elderly who use a hearing aid device reported having difficulties to use the telephone bobbin and volume control ${ }^{(18,19)}$, and $85 \%$ of experienced users needed to reanalyze the guidelines concerning telephone usage ${ }^{(20)}$.

This result reinforces the need to provide counseling and information, the so-called "guidance", not only in the early stages of hearing aid usage, but also with time, in follow-up appointments, considering that patients usually do not recall information provided during the first appointments. Therefore, it is necessary to repeat it throughout the process, using support materials that favor retention ${ }^{(21)}$.

In fact, an international study ${ }^{(20)}$ demonstrated the need for annual follow-ups in order to promote the benefit with the use of hearing aid devices, mentioning that such follow-ups were wanted by $86 \%$ of the users of the service.

In Brazil, it is recommended that the public services of hearing habilitation and rehabilitation provide periodical followup for the patients, which includes, among other procedures, the monitoring of hearing aid usage. Among people aged more than 17 years old, it is recommended that this follow-up be conducted up to twice a year ${ }^{(22)}$.

The availability of instructions addressed to teaching how to use and care for the hearing aid device is considered to be important by the users ${ }^{(19)}$. Besides, multimedia materials proved to be efficient to increase the retention of information concerning the handling of hearing aid devices, therefore they can be complementary to guidance in person ${ }^{(23)}$.

The use of hearing aid devices reduced the self-perception of restricted participation, as demonstrated by the results of HHIA/E (Table 3). The positive impact of hearing aid usage in comparison to the perception of social and emotional disadvantages resulting from hearing loss was already reported in literature ${ }^{(24,25)}$.

Concerning IOI, maximum or close to maximum scores were obtained for all of the items in the inventory (Table 3), and such results were very superior to the norms of this assessment instrument ${ }^{(26)}$. However, other studies also observed higher results in relation to the norm, therefore this can be a consequence of the different technology employed in the hearing aid 
Table 5. Spearman correlation ( $r$ ) between Practical Hearing Aid Skills Test results and sociodemographic and audiological results of participants $(n=74)$

\begin{tabular}{lcccccccc}
\hline \multirow{2}{*}{ Sociodemographic data } & \multicolumn{9}{c}{ PHAST tasks } & \multicolumn{1}{c}{ PHAST (\%) } \\
\cline { 2 - 9 } & 1 & 2 & 3 & 4 & 5 & 6 & -0.25 & -0.21 \\
Age & 0.07 & 0.01 & -0.11 & -0.22 & -0.12 & -0.18 & -0.06 & 0.10 \\
Hearing threshold & 0.13 & 0.13 & 0.02 & -0.01 & 0.05 & 0.31 & 0.11 & 0.27 \\
Schooling & 0.19 & 0.23 & 0.07 & 0.31 & 0.13 & 0.20 & 0.11 \\
\hline
\end{tabular}

*Significant values $(p \leq 0.005)$

Caption: PHAST = Practical Hearing Aid Skills Test

devices used or of the characteristics of the assessed population $^{(27,28)}$. It is important to mention that, in Brazil, high satisfaction results are commonly found when users of public hearing services are evaluated. Patients in SUS are usually grateful to the provided services, therefore they do not see themselves as citizens with rights in face of the public service, which makes it difficult to assess the real perspective of the user ${ }^{(29)}$. The fact that IOI-HA was applied by means of an interview may also have influenced the responses.

No correlation was found between HHIA/E scores and PHAST scores. With regard to IOI-HA, positive and significant moderate correlations were found between the benefit of hearing aid usage ("How much did this device help in a situation in which you wanted to hear better?"), quality of life ("How much did this device change your pleasure of living?"), and the handling skills with the hearing aid device (Table 4). Authors ${ }^{(30)}$ also observed that the facility to handle the hearing aid device influenced the benefit obtained by this device.

Another study ${ }^{(5)}$ did not show any correlation between the results of PHAST and the measurements of benefit concerning the limited activities and the satisfaction with the hearing aid usage. This may have occurred because of the different instruments used to assess the results adopted for each study.

No correlations between age and handling skills were observed. Literature showed poor significant negative correlations between age and PHAST results ${ }^{(5,16)}$, and such results were partly attributed to work memory deficits and manual skills, related to age. In this study, these relationships may not have been observed because the participants were mostly elderly, and $60 \%$ of them were above 70 years old.

Likewise, as observed in the literature ${ }^{(5,16)}$, this study did not show a relation between the level of hearing loss and the level of schooling with the performance of hearing aid handling (Table 5).

\section{CONCLUSION}

There was no difference as to the handling skills with a hearing aid device among new and experienced users. Such handling skills are related to the general benefit obtained by this device.

\section{ACKNOWLEDGMENT}

We would like to thank the Institutional Scientific Initiation Program of USP - RUSP modality, for the support in the conduction of this study, process number 2012.1.04019.25.7.
*PDC participated in the data collection, supervised, directed and discussed the implementation of the tasks. $A B$ was responsible for collecting and tabulating the data and collaborated effectively in the preparation of the manuscript. DVF guided the research project, corrected, discussed the data and participated in drafting the manuscript's data.

\section{REFERENCES}

1. Brasil. Ministério da Saúde. Portaria GM/MS no. 2073, de 28 de setembro de 2004. Institui a Política Nacional de Atenção à Saúde Auditiva. Diário Oficial da União, 2004 Set 29.

2. Brasil. Ministério da Saúde. Portaria no. 793, de 24 de abril de 2012. Institui a rede de cuidados à pessoa com deficiência no âmbito do Sistema Único de Saúde. Diário Oficial da União, 2012 Abr 25.

3. DATASUS. Brasil: DATASUS; 2013 [cited 2013 Set 15]. Available from: http://tabnet.datasus.gov.br.

4. Vuorialho A, Karinen P, Sorri M. Counselling of hearing aid users in highly cost-effective. Eur Arch Otorhinolaryngol. 2006;263(11):988-95.

5. Desjardins JL, Doherty KA. Do experienced hearing aid users know how to use their hearing AIDS correctly? Am J Audiol. 2009;18(1):69-76.

6. Bertolucci PHF, Brucki SMD, Campacci SR, Juliano Y. O mini-exame do estado mental em uma população geral: impacto da escolaridade. Arq Neuropsiquiatr. 1994;52(1):1-7.

7. Campos PD, Ferrari DV, Bastos BG, Campos K, Blasca WQ. Teste das habilidades de manuseio dos aparelhos de amplificação sonora individuais - resultados preliminares. $26^{\circ}$ Encontro Internacional de Audiologia; 2011 Abr 17-20; Maceió, AL

8. Guillemin F, Bombardier C, Beaton D. Cross-cultural adaptation of health-related quality of life measures: literature review and proposed guidelines. J Clin Epidemiol. 1993;46(12):1417-32.

9. Doherty KA, Desjardins JL. The practical hearing aids skills test-revised. Am J Audiol. 2012;21(1):100-5.

10. Vestergaard MD. Self-report outcome in new hearing-aid users: longitudinal trends and relationships between subjective measures of benefit and satisfaction. Int J Audiol. 2006;45(7):382-92.

11. Newman CW, Weinstein BE, Jacobson GP, Hug GA. The hearing handicap inventory for adults: psychometric adequacy and audiometric correlates. Ear Hear. 1990;11(6):430-3.

12. Ventry IM, Weinstein BE. The hearing handicap inventory for the elderly: a new tool. Ear Hear. 1982;3(3):128-34.

13. Almeida K. Avaliação objetiva e subjetiva do benefício de próteses auditivas em adultos [tese]. São Paulo: Universidade Federal de São Paulo; 1998.

14. Wieselberg MB. A auto-avaliação do handicap em idosos portadores de deficiência auditiva: o uso do HHIE [dissertação]. São Paulo: Pontifícia Universidade Católica de São Paulo; 1997.

15. Cox RM, Alexander GC. The International Outcome Inventory for Hearing Aids (IOI-HA): psychometric properties of the English version. Int J Audiol. 2002;41(1):30-5.

16. Jokura PR. Aconselhamento informativo para adultos e idosos usuários de aparelho de amplificação sonora individual: avaliação da eficácia de um material online [dissertação]. Bauru: Faculdade de Odontologia de Bauru da Universidade de São Paulo; 2013.

17. Veras RP, Mattos LC. Audiologia do envelhecimento: revisão da literatura e perspectivas atuais. Rev Bras Otorrinolaringol. 2007;73(1):128-34. 
18. Barros PFS, Queiroga BAM. As dificuldades encontradas no processo de adaptação de aparelho de amplificação sonora individual em indivíduos idosos. Rev CEFAC. 2006;8(3):375-85.

19. Campos K, Oliveira JRM, Blasca WQ. Processo de adaptação de aparelho de amplificação sonora individual: elaboração de um DVD para auxiliar a orientação a indivíduos idosos. Rev Soc Bras Fonoaudiol. 2010;15(1):19-25.

20. Goggins S, Day J. Pilot study: efficacy of recalling adult hearing-aid user for reassessment after three years within a publicly-funded audiology service. Int J Audiol. 2009;48(4):204-10.

21. Geraldo T, Ferrari DV, Bastos BG. Orientação ao usuário de prótese auditiva: retenção da informação. Arquivos Int Otorrinolaringol. 2011;15(4):410-7.

22. Brasil. Ministério da Saúde. Instrutivo Saúde Auditiva. Ref. Portaria GM 79 de 24 de abril de 2012 e Portaria GM 835 de 25 de abril de 2012. Diário Oficial da União, 2013 Abr.

23. Locaputo-Donnellon AE, Clark JG. Hearing aid orientation supplement through DVD instruction. Hearing Journal. 2011;64(3):44-50.
24. Luz VB, Silva MC, Scharlach RC, Iório MCM. Correlação entre as restrições de participação em atividades de vida diária e o benefício do uso de próteses auditivas em adultos e idosos. Rev Soc Bras Fonoaudiol. 2011;16(2):160-6.

25. Amorim RMC, Almeida K. Estudo do benefício e da aclimatização em novos usuários de próteses auditivas. Pró-Fono R Atual Cient. 2007;19(1):39-48.

26. Cox RM, Alexander GC, Beyer CM. Norms for the international outcome inventory for hearing aids. J Am Acad Audiol. 2003;14(8):403-13.

27. Liu H, Zhang H, Liu S, Chen X, Han D, Zhang L. International outcome inventory for hearing aids (IOI-HA): results from the Chinese version. Int J Audiol. 2011;50(10):673-8.

28. Smith SL, Noe CM, Alexander GC. Evaluation of the International Outcome Inventory for Hearing Aids in a veteran sample. J Am Acad Audiol. 2009;20(6)374-80.

29. Bevilacqua MC, Melo TM, Morettin M, Lopes AC. A avaliação de serviços em Audiologia: concepções e perspectivas. Rev Soc Bras Fonoaudiol. 2009;14(3):421-6.

30. Baumfield A, Dillon H. Factors affecting the use and perceived benefit of ITE and BTE hearing aids. Br J Audiol. 2001;35(4):247-58. 